\title{
The Analysis of Factors that Affecting the Amount of Free- Range Chicken Meat's Consumption in Langkat Regency
}

\author{
S Aisyah, I Sembiring, Hasnudi, Yunilas, E Mirwandhono \\ Animal Production Program Study, Faculty of Agriculture, University of North \\ Sumatera, Medan 20155, Indonesia \\ E-mail: Sitiaisha055@gmail.com
}

\begin{abstract}
Chicken meat is one of the livestock commodities that can meet the protein needs of the community, but there are constraints on the price side. The price of free-range chicken meat tends to fluctuate due to production and demand imbalances and has an impact on price increases. Therefore, there needs to be control so that price increases that occur in free-range chicken meat do not jump sharply

The purpose of the study was to determine the factors that influence the amount of freerange chicken meat's consumption in Langkat Regency. The study was conducted in June August 2018. The method that used in sampling was the proportionate stratified random sampling method and used the Slovin formula. Primary data collection was carried out by interview techniques using questionnaires to respondents and secondary data collection was obtained from the agencies and agencies assembled and then analyzed with Multiple Linear Regression using SPSS 22 application.

The results showed the amount of free-range chicken meat's consumption in Langkat Regency was influenced partially by income and the number of family members with $\mathrm{R}^{2}=$ 0.61 .
\end{abstract}

\section{Introduction}

Free-range chicken meat is one of the livestock commodities that can meet the protein needs of the community and is one of the livestock foods that is a favorite in the community. They claim that consuming free-range chicken meat is healthier, besides that the taste of the meat is more savory and drier than broiler chicken [1].

In terms of commodity marketing, free-range chicken farmers did not experience significant problems because the number of free-range chicken consumers was quite large. Constraints are felt on the price side. The price of free-range chicken meat tends to fluctuate which is influenced by the high and low demand of the market. Therefore, there needs to be control so that price increases that occur in freerange chicken meat do not increase sharply [2].

Langkat Regency is one of the districts in North Sumatra province which produced the highest freerange chicken production in 2016, which was 1,534,966 / ton / year after the city of Mandailing Natal as many as 27,981,086/ton/year and Serdang Bedagai district as much as 2,261,592/ton/year (Central Statistics Agency of Langkat Regency, 2017) [3].

According to Hutagallung (2013) from the demand side that the age variable, the price of free-range chicken partially, the education level did not significantly affect the amount of free-range chicken consumption, while the number of dependents and income significantly affected the amount of freerange chicken consumption. Based on this, the authors are interested in conducting a study entitled "Analysis of Factors that Affect the Consumption of free-range chicken in the Village of Langkat" [4]. 


\section{Materials and Methods}

\subsection{Time and place of research}

This research was conducted in June - August 2018 in Stabat Subdistrict, Wampu Subdistrict, and Sawit Seberang Subdistrict in Langkat District, North Sumatra Province.

\subsection{Research Methods and Sampling}

This research was carried out using survey methods using questionnaires by taking several samples from the population. Household sampling was determined by the proportionate stratified random sampling method using the Slovin formula. The total number of samples is 290, of which 98 are in the Stabat sub-district, 96 in the Wampu sub-district and 96 in the SawitSeberang sub-district.

\subsection{Method of collecting}

The data used in this study are primary data and secondary data. Primary data was directly collected from households as respondents according to the questionnaire/questionnaire that had been made previously. Secondary data was obtained from relevant agencies and agencies such as the Livestock Service Office, Langkat Regency Central Bureau of Statistics, North Sumatra Province Central Bureau of Statistics and other literature such as journals and research results that support this research.

\subsection{Data analysis method}

The method used is inductive analysis, which is calculated by estimating multiple linear regression with a tool is the SPSS 22 program.

Multiple Linear Regression Analysis

Where the estimation model of multiple linear analysis is as follows:

$$
Y=a+b 1 X 1+b 2 X 2+b 3 X 3+b 4 X 4+b 5 X 5+\mu
$$

informations:

$\mathrm{Y}=$ Amount of free-range chicken meat consumption ( $\mathrm{kg} / \mathrm{month})$

$\mathrm{a}=$ Intersep Constant/Coefficient

b1-b6 = Coefficient of regression variable

$\mathrm{X} 1=$ Income/month

$\mathrm{X} 2=$ Price of free-range chicken meat $(\mathrm{Rp} / \mathrm{kg})$

$\mathrm{X} 3=$ Number of family members (souls)

$\mathrm{X} 4=$ Price of substitute commodity/broiler chicken $(\mathrm{Rp} / \mathrm{Kg})$

X $5=$ Public perception (score)

$\mu=$ Intruder errorUjiPenyimpanganAsumsiKlasik

In order to produce a BLUE (Best Linear Unbias Estimator) regression model, it is necessary to do a Classic Assumption Test.

\subsection{Classic Assumption Test}

The classic assumption test used in this study is:

1. Multicollinearity test

Multicollinearity test aims to test whether there is a linear relationship between the independent variables in the regression.

2. The heteroscedasticity test

The heteroscedasticity test aims to test whether in the regression model variance occurs from the residual inequality one observation to another observation. 
1. Coefficient of Determination $\left(\mathrm{R}^{2}\right)$

It is a measure of the extent to which independent variables can change the dependent variable in a relationship. This coefficient shows the percentage of free variation. The coefficient of determination $\left(R^{2}\right)$ ranges from $0<R^{2}<1$ with the test criteria being $R^{2}$ which is closer to 1 indicating the model formed is able to explain the diversity of the dependent variable.

2. Simultan Significance Test(Test F)

The $\mathrm{F}$ test is a simultaneous test of the effect of independent variables on fixed variables.

Test criteria

- If sig. $\mathrm{F} \leq 0.05, \mathrm{H} 0$ is rejected and $\mathrm{H} 1$ is accepted

- If sig. F>0.05 then $\mathrm{H} 0$ is accepted and $\mathrm{H} 1$ is rejected

3. Individual Significance Test (t Test)

The $\mathrm{t}$ statistical test is conducted to find out how much influence each independent variable individually influences the variation of the dependent variable.

Test criteria:

1. If sig. $\mathrm{t} \leq 0.05$ then $\mathrm{H} 0$ is rejected and $\mathrm{H} 1$ is accepted

2. If sig. $\mathrm{t}>0.05$ then $\mathrm{H} 0$ is accepted and $\mathrm{H} 1$ is rejected

To analyze the development of chicken meat prices in Langkat district analyzed using descriptive analysis method based on data on free-range chicken meat prices in Langkat Regency.

\section{Results and Discussion}

\subsection{Regression Equation}

Based on the attachment, the regression equation of the factors that influence the demand for freerange chicken meat in Langkat Regency are as follows:

$Y=0,375+0,000000681 \mathrm{X} 1-0,000008334 \mathrm{X} 2+0,147 \mathrm{X} 3-0,000009241 \mathrm{X} 4+0,002 \mathrm{X} 5$

Where :

$\mathrm{Y}=$ Amount of free-range chicken meat consumption $(\mathrm{kg} / \mathrm{month})$

$\mathrm{a}=$ Intersep Constant/Coefficient

b1-b6 =Coefficient of regression variable

$\mathrm{X} 1$ = Revenue/month

$\mathrm{X} 2=$ Price of free-range chicken meat $(\mathrm{Rp} / \mathrm{Kg})$

$\mathrm{X} 3$ =Number of family members (soul)

$\mathrm{X} 4=$ Substitution commodity price / broiler chicken $(\mathrm{Rp} / \mathrm{Kg})$

$\mathrm{X} 5$ = Community perception (score)

$\mu=$ Disturbing error

3.2 Classic assumption test

1. Multicollinearity Test

\begin{tabular}{ccccccc}
\hline & \multicolumn{2}{c}{ Unstandardized Coefficients } & $\begin{array}{c}\text { Standardized } \\
\text { Coefficients }\end{array}$ & \multicolumn{2}{c}{ Collinearity Statistics } \\
\cline { 2 - 7 } & \multicolumn{1}{c}{ Model } & 0,375 & Std. Error & Beta & Tolerance & VIF \\
\hline $1 \quad \begin{array}{l}\text { (Constant) } \\
\text { Income }\end{array}$ & $6,81 \mathrm{E}-07$ &, 000 & 0,738 & 0,842 & 1,188 \\
$\begin{array}{l}\text { Price of free-range } \\
\text { chicken meat }\end{array}$ & $-8,33 \mathrm{E}-06$ &, 000 & $-0,023$ & 0,96 & 1,042 \\
$\begin{array}{l}\text { Number of family } \\
\text { members }\end{array}$ & 0,147 & 0,042 & 0,138 & 0,88 & 1,137 \\
$\begin{array}{l}\text { Substitution } \\
\text { commodity price / }\end{array}$ & $-9,24 \mathrm{E}-06$ &, 000 & $-0,03$ & 0,988 & 1,012 \\
$\begin{array}{l}\text { broiler chicken } \\
\text { Community }\end{array}$ & 0,002 & 0,013 & 0,006 & 0,98 & 1,021 \\
\hline
\end{tabular}


The multicollinearity test aims to test whether there is a linear relationship between the independent variables in the regression. Based on the table that VIF on each independent variable $<10$ and tolerance value on each independent variable> 0.10 , it can be interpreted that there is no multicollinearity in the data analyzed.

2. Heterocedasticity test

Heteroscedasticity test aims to test whether in the regression model variance occurs from the residual inequality one observation to another observation. To find out, it is necessary to do a glejser test in the table and get the results that all $\mathrm{p}=$ value independent variable $>0.05$ can mean that there is no heterocedasticity.Heterocedasticity test can be seen in the following table:

\begin{tabular}{lcc}
\hline \multicolumn{1}{c}{ Model } & T-value & P-value \\
\hline (Constant) & 1,237 &, 217 \\
Income & 1,581 &, 115 \\
Price of free-range chicken meat &,- 656 &, 512 \\
Number of family members & $-1,155$ &, 249 \\
Substitution commodity price / & 1,162 &, 246 \\
broiler chicken & $-1,390$ &, 166 \\
Community perception & & \\
\hline
\end{tabular}

\subsection{Statistic test}

1. Coefficient of Determination (R2)

Based on the analysis found the coefficient of determination 0.616 which means that the independent variables that have been used are able to influence the dependent variable Y by $61 \%$ while $39 \%$ is influenced by other factors not included in the demand function $(\mathrm{Y})$.

2. Simultan Significance Test (F)

The F Test Table can be seen in the following table:

\begin{tabular}{lrrrrr}
\hline Model & Sum of Squares & \multicolumn{1}{c}{ Df } & Mean Square & \multicolumn{1}{c}{ S } & \multicolumn{1}{c}{ Sig. } \\
\hline Regression & 109,515 & 5 & 21,903 & 91,063 &, $000^{\mathrm{b}}$ \\
Residual & 68,309 & 284 &, 241 & & \\
\hline Total & 177,824 & 289 & & & \\
\hline
\end{tabular}

The whole independent variable is said to affect the fixed variable if the value of F-count> F-table or probability value is smaller than 0.05 . Based on the table above, it is found that the probability value is less than 0.05 , which means income, price of native chicken meat, number of family members, prices of substitute commodities (broiler chicken), and community perceptions simultaneously affect the amount of consumption of native chicken meat.

3. Individual Significance Test (Uji t)

\begin{tabular}{lcc}
\hline Model & t-hitung & P-value \\
\hline (Constant) &, 508 &, 612 \\
Income & 18,149 &, 000 \\
Price of free-range chicken meat &,- 620 &, 536 \\
Number of family members & 3,510 &, 001 \\
Substitution commodity price / broiler &,- 823 &, 411 \\
chicken &, 153 &, 879
\end{tabular}

Partial testing is done to find out how much influence each of the independent variables individually explains the dependent variation in Langkat Regency. If the independent variable has a probability smaller than 0.05 then the variable significantly affects the amount of consumption of free-range chicken meat. T test table (partial test) can be seen in the following table. 
Based on the table above, it can be explained as follows:

a. The independent variable (X1) partially has a significant influence on the demand for free-range chicken meat (Y). Has a probability value of 0,000 less than 0.05 .

b. The independent variable (X2) partially has a non-significant effect on the demand for free-range chicken meat $(\mathrm{Y})$. Has a probability value of 0.536 greater than 0.05 .

c. The independent variable (X3) partially has a significant influence on the demand for free-range chicken meat (Y). Has a probability value of 0.001 smaller than 0.05 .

d. The independent variable (X4) partially has a non-significant effect on the demand for free-range chicken meat $(\mathrm{Y})$. Has a probability value of 0.411 greater than 0.05 .

e. The independent variable (X2) partially has a non-significant effect on the demand for free-range chicken meat $(\mathrm{Y})$. Has a probability value of 0.879 greater than 0.05 .

Factors Affecting the Consumption of Village free-range chicken meat in Langkat District

1. Income

Based on the results of the t-test analysis, it is found that the income variable has a probability value of 0.00 less than 0.05 , which means that income significantly affects the amount of free-range chicken meat consumption in Langkat Regency. This is in accordance with Sinaga's research (2013) that income has a significant effect on the amount of free-range chicken meat consumption in West Siantar District, PematangSiantar City. And according to Hutagalung (2013) that income significantly affects the amount of chicken meat consumption in the Sambas market in Medan City. Based on the regression analysis that the coefficient value of family income is 0.000000681 and is positive, which means that every increase of Rp 1 family income will increase the amount of free-range chicken meat consumption by 0.000000681 or every increase in income of Rp1,000,000.00 will increase the amount consumption of free-range chicken meat is $0.681 \mathrm{~kg}$.

\section{Price of free-range chicken meat}

Based on the results of the t-test analysis, it was found that the variable price of free-range chicken meat had a probability value of 0.536 greater than 0.05 , which means that the price of free-range chicken meat did not significantly affect the amount of free-range chicken meat consumption in Langkat District. This is in line with the research of Sinaga (2013) that the price of free-range chicken meat does not affect the amount of free-range chicken meatconsumption in the West Siantar District of PematangSiantar City and Hutagallung (2013) that the price of free-range chicken meat does not affect the amount of free-range chicken meatconsumption in the Sambas market in Medan . Based on the regression analysis that the coefficient value of the price of free-range chicken meat is 0.000008334 and has a negative sign which means that every increase in the price of free-range chicken meatby Rp 1 will reduce the demand of free-range chicken meat is $0.000008334 \mathrm{~kg}$.

\section{Number of family members}

Based on the results of the t-test analysis the results of the variable number of family members have a probability value of 0.001 smaller than 0.05 , which means that the number of family members affects the amount of free-range chicken meat in Langkat District. This is in line with Hutagalung's (2013) research that the number of dependents is very influential on the amount of free-range chicken in the Sambas market in Medan City. So that the analysis of the coefficient value of family members is 0.147 and has a positive sign, which means that each family member is 1 soul, increasing the amount of free-range chicken meat is $0.147 \mathrm{~kg}$.

\section{Substitution commodity price / broiler chicken)}

Based on the results of the t-test analysis it was found that the price variable substitution commodity (broiler chicken) has a probability value of 0.411 greater than 0.05 , which means that the price of substitute commodities (broiler chicken) does not significantly affect the amount of free-range chicken meat consumption in Langkat Regency . This is in accordance with the opinion of Sinaga (2013) that the price of substitute commodities does not significantly affect the amount of free-range chicken meat consumption in the West Siantar District of Pemtangsiantar City. Based on the regression analysis that the coefficient value of substitute commodity prices (broiler chicken) is 
0.000009241 and is negative, which means that every increase in the price of broiler chicken meat by Rp 1 will reduce the amount of free-range chicken meat consumption is $0.000009241 \mathrm{~kg}$.

\section{Community perception}

From the results of research conducted in Langkat Regency, the average score of community perception in consuming chicken meat was 18.95 where the highest community perception score was 24 and the lowest perception score was 14.Based on the results of the t-test analysis, it was found that the public perception variable had a probability value of 0.879 greater than 0.05 , which meant that public perceptions did not significantly affect the amount of free-range chicken meat consumption of Langkat Regency. This is because the price of free-range chicken meat is quite expensive so the decision to consume free-range chicken meat is influenced by family income and the number of family members. Based on the regression analysis that the coefficient value of public perception is 0.002 and is positive, which means that the better and higher the score of public perception will increase the amount of consumption of free-range chicken meat is $0.002 \mathrm{~kg}$.

\subsection{Development of Village Free-range Chicken Meat Prices in Langkat Regency}

\begin{tabular}{cccccc}
\hline Information & January & February & March & April & May \\
\hline $\begin{array}{c}\text { Price } \\
(\mathrm{Rp} / \mathrm{Kg})\end{array}$ & $35.526,00$ & $35.421,00$ & $35.000,00$ & $35.550,00$ & $40.000,00$ \\
\hline
\end{tabular}

From the table above, the development of prices for free-range chicken meat has fluctuated depending on the high and low demand of consumers. And in May there was an increase due to nearing the month of Ramadan and Eid. This is in accordance with Rasyaf's opinion (2010) that the price of freerange chicken meat tends to fluctuate which is influenced by the high and low market demand. Especially in certain months ahead of religious holidays such as Eid, Eid Hajj, Christmas and New Year, or traditional ceremonies, the demand for chicken meat surged. With the increase in demand, the price of free-range chicken meat is inevitably fluctuating. In January the average price of freerange chicken was IDR 35,526.00 / Kg, in February the average price of free-range chicken was IDR $35,421.00 / \mathrm{Kg}$, in March the average price of free-range chicken meat experienced a slight decrease of IDR $35.000,00 / \mathrm{Kg}$ and in April to May the average price of native chicken meat has increased by Rp. 35,550.00 / Kg and Rp. 40,000.00 / Kg.

\section{Conclusions}

The income factor and the number of family members influence each of these factors on the amount of free-range chicken meat consumption, while the price factor forfree-range chicken meat, the price of substitute commodities (broiler chicken) and community perceptions do not affect each of these factors on the amount of free-range chicken meat consumption village.

\section{References:}

[1] Badan Pusat Statistik Kabupaten Langkat. 2017. Kabupaten Langkat Dalam Angka.

[2] Hutangallung, B., O., S. 2013. AnalisisFaktor-Faktor yang Mempengaruhi Perilaku Konsumen Terhadap Daging Ayam Kampung di Kota Medan. FakultasPertanian, Univeristas Sumatera Utara.

[3] Rasyaf, Muhammad. 2010. ManajemenPeternakanAyamKampung. Yogyakarta: Kanisius.

[4] Sinaga, A. 2013. AnalisisFaktor-faktor Yang MempengruhiPermintaanDagingAyamKampung di KecamatanSiantar Barat Kota Pematangsiantar. FakultasPertanian. Universitas SumateraUtara. 